\title{
PENENTUAN DUA LOKASI LUMBUNG PADI DENGAN MENGGUNAKAN METODE GRID DI PROVINSI KALIMANTAN TENGAH
}

\author{
Yunita Puput Wijayanti' ${ }^{1}$ Adi Setiawan², Hanna Arini Parhusip ${ }^{3}$ \\ 1,2,3 Prodi Matematika, Fakultas Sains dan Matematika, Universitas Kristen Satya Wacana \\ Email: ${ }^{1662015020 @ s t u d e n t . u k s w . e d u, ~}{ }^{2}$ adi.setiawan@staff.uksw.edu, ${ }^{3}$ hanna.arini@staff.uksw.edu
}

(Naskah masuk: 04 Februari 2019, diterima untuk diterbitkan: 11 November 2019)

\begin{abstract}
Abstrak
Perancangan lokasi pendistribusian pangan merupakan salah satu kegiatan yang dilakukan pemerintah untuk memenuhi kebutuhan pokok pangan masyarakat yang bisa berubah secara dinamis dari waktu ke waktu. Metode Grid diaplikasikan dalam penelitian ini untuk menentukan lokasi yang tepat untuk lumbung padi dalam upaya pendistribusian bahan pangan di Provinsi Kalimantan Tengah dengan memperhatikan jarak dan biaya transportasi. Tidak hanya itu, dengan bantuan metode grid untuk penentuan kandidat lokasi lumbung padi juga membantu dalam proses penelitian. Berdasarkan data yang berupa koordinat lokasi kantor kabupaten, jumlah penduduk, dan banyaknya produksi padi di Provinsi Kalimantan Tengah dapat diperoleh dua lokasi lumbung padi terdapat pada koordinat geografis $(-1.8,113.0)$ tepatnya di Desa Koeling, Kecamatan Pundu, Kabupaten Kotawaringin Timur, Kalimantan Tengah dan (-3.0,114.2) tepatnya di Desa Pangkuh, Kecamatan Pangkoh Hilir, Kabupaten Pulang Pisau, Kalimantan Tengah dengan total cost sebesar Rp. 55,287,393.08.
\end{abstract}

Kata kunci: lumbung padi, metode grid, Provinsi Kalimantan Tengah

\section{DETERMINATION TWO OF GRANARY LOCATION USING GRID METHOD IN CENTRAL BORNEO PROVINCE}

\begin{abstract}
The design of food distribution location is one of the goverment activity to fulfill the main need of society that can change dynamically over time. The Grid method was applied in this study to determine the exact location the granary for the distribution of food in Central Borneo Province by pay attention distance and transportation cost. Not only that, with the help of the grid method for determining candidates for granary locations it also help in the research process. Based on the data in the form of the coordinates of the location of the district office, population, and the amount of rice production in Central Borneo Province, two granary locations are located at the geographical coordinates (-1.8,113.0) precisely in Koeling Village, Pundu Sub-district, East Kotawaringin District, Central Borneo, and (-3.0,114.2) precisely in Pangkuh Village, Pangkoh Hilir Sub-district, Pulang Pisau District, Central Borneo with a total cost Rp. 55,287,393.08.
\end{abstract}

Keywords: granary, grid method, Central Borneo Province

\section{PENDAhuluan}

Pangan atau yang biasa disebut bahan makanan merupakan salah satu dari ketiga kebutuhan primer bagi makhluk hidup. Makanan juga menjadi kebutuhan utama untuk kelangsungan hidup dimanapun mereka berada, tidak terkecuali bagi penduduk di suatu negara termasuk Indonesia. Pada umumnya kebutuhan bahan pangan utama masyarakat di Indonesia adalah beras. Namun selain beras, masyarakat Indonesia juga mengonsumsi berbagai jenis ikan, umbi-umbian, dan biji-bijian (Utama, 2007)

Indonesia merupakan negara berkembang yang dikenal dengan sebutan negara agraris, dimana bidang pertanian memegang peranan cukup penting dari sekian banyak bidang dalam perekonomian nasional. Namun fakta negara Indonesia merupakan negara agraris ini belum menjanjikan bahwa kebutuhan bahan pangan tiap daerah di Indonesia telah mampu tercukupi dari dalam daerah tersebut. Karena makanan atau dalam hal ini adalah bahan pangan adalah kebutuhan masyarakat untuk hidup dalam suatu daerah maka pemerintah juga ikut bertanggung jawab atas ketersediaannya bahan pangan tersebut. Seperti halnya pemerintah Provinsi Kalimantan Tengah yang bertanggung jawab atas kesejahteraan masyarakat yang menyangkut ketersediaannya bahan pangan. Selayaknya Negara 
Indonesia, Provinsi Kalimantan Tengah yang merupakan bagian kecil dari negara Indonesia ini juga memiliki bahan pangan mayoritas padi atau beras. Sehingga ketersediaan beras di setiap daerah Provinsi Kalimantan Tengah cukup diperhatikan.

Provinsi Kalimantan Tengah terdiri dari 14 kabupaten dengan luas wilayah sebesar 153,564.5 $\mathrm{km}^{2}$ ini memiliki jumlah produksi bahan pangan yang berbeda di tiap kabupatennya. Dari jumlah hasil produksi padi tersebut terdapat kabupaten yang mengalami kekurangan bahan pangan, sehingga perlu mengambil pasokan padi dari kabupaten lain yang berlebih, seperti Kabupaten Kotawaringin Timur. Hal tersebut dipengaruhi oleh beberapa faktor, salah satunya adalah faktor jumlah penduduk. Dalam pengambilan pasokan bahan pangan, diperlukan transportasi untuk memindahkan bahan makanan tersebut sehingga biaya transportasi juga menjadi kendala tersendiri dalam upaya penyejahteraan masyarakat Provinsi Kalimantan Tengah. Oleh karena itu, diperlukan lumbung padi untuk menampung bahan pangan yang berlebih, sehingga kabupaten yang pada saat itu mengalami kekurangan bahan pangan lebih mudah dalam mengambil pasokan dan juga untuk mengurangi biaya transportasi.

Pada penelitian ini diusulkan metode grid untuk menentukan lokasi yang ideal untuk lumbung padi di Provinsi Kalimantan Tengah. Metode grid adalah suatu metode yang digunakan untuk menentukan lokasi suatu fasilitas seperti gudang atau pabrik yang memperhitungkan suatu faktor dalam hal ini adalah faktor total biaya yang digunakan untuk pendistribusian bahan pangan padi. Sedangkan lokasi yang ideal adalah lokasi yang membuat jarak tertimbang antara lokasi lumbung dan lokasi pemasok menjadi minimal, jarak ini diberi bobot sesuai dengan banyaknya bahan pangan yang diangkut. Untuk melakukan perhitungan dengan metode ini diperlukan koordinat lokasi yang akan menerima pasokan padi atau lokasi kabupaten yang berupa koordinat longitude dan latitude dari Google Maps yang dalam hal ini diwakili oleh kantor bupati untuk ditransformasikan ke koordinat UTM (Universal Tranverse Mercator) sebagai dasar perhitungan dan jumlah volume bahan pangan baik yang berlebih maupun yang berkurangan berdasarkan jumlah produksi padi dari masing-masing kabupaten yang berada di Provinsi Kalimantan Tengah. Adapun koordinat UTM adalah sistem koordinat yang menggunakan metode berbasis grid untuk menentukan lokasi di permukaan bumi yang berbasis dua dimensi. Metode ini juga digunakan untuk meminimumkan biaya yang dipakai untuk transportasi yang akan dikeluarkan pemerintah Provinsi Kalimantan Tengah. Pada prinsipnya berdasarkan luas wilayah Provinsi Kalimantan Tengah yang cukup besar, jumlah lokasi lumbung padi yang dapat ditentukan dapat berjumlah lebih dari dua buah, namun dalam penelitian ini akan ditentukan dua buah lokasi lumbung padi. Setelah mengetahui koordinat lokasi kedua lumbung padi, digunakan aplikasi Google Maps untuk menentukan peta lokasi sesungguhnya pada permukaan bumi.

Berikut beberapa kajian dari literaturliteratur sebelumnya yang berkaitan dengan penelitian ini. Saraswati (2015) yang melakukan penelitian dengan menggunakan metode grafitasi untuk menentukan lokasi gudang pada bisnis rentail di Kota Bandung dan sebagai alat evaluasi. Ama, dkk (2015) melakukan penelitian dengan metode GLM untuk menentukan lokasi lumbung padi di Minahasa Tenggara. Hasna, dkk (2017) melakukan penelitian dengan menggunakan metode GLM untuk menentukan lokasi lumbung pangan di Provinsi Maluku Utara. Dari ketiga penelitian diatas, penentuan lokasi belum ada yang menggunakan metode grid.

Dalam penelitian yang dilakukan oleh Setiawan dan Sediyono (2015) menjelaskan penggunaan metode grid untuk menentukan lumbung padi di Minahasa Tenggara. Dalam keempat penelitian di atas lokasi yang diperhitungkan di setiap penelitian hanya memperhatikan satu zona UTM saja, sedangkan dalam penelitian ini mencakup dua zona UTM yang diperhitungkan.

\section{KOORDINAT UTM}

Koordinat UTM atau Universal Transverse Mercator adalah suatu aplikasi praktis dengan menggunakan metode grid untuk menentukan suatu titik lokasi tertentu di permukaan bumi dimana titik tersebut akan dinyatakan dalam bentuk dua dimensi. Sistem koordinat ini dikembangkan tahun 1940-an oleh perusahaan yang bernama United States Army Corps of Enginners. Berdasarkan koordinat UTM permukaan bumi terbagi dalam beberapa zona. Zona bagian datar yang membentuk garis vertikal terdapat 60 zona, hal ini berdasarkan longitude pada koordinat geografis serta 20 zona berdasarkan pada latitudenya. Hasil dari koordinat UTM ini berupa Easting (E) dan Northing (N) serta zona lokasi tersebut. Adapun persamaan yang digunakan untuk mengkonversikan koordinat Geografis ke koordinat UTM dapat dilihat pada persamaan milik Hager, dkk (1989).

Pada Gambar 1 berikut ini diberikan gambar mengenai pembagian zona dalam koordinat UTM.

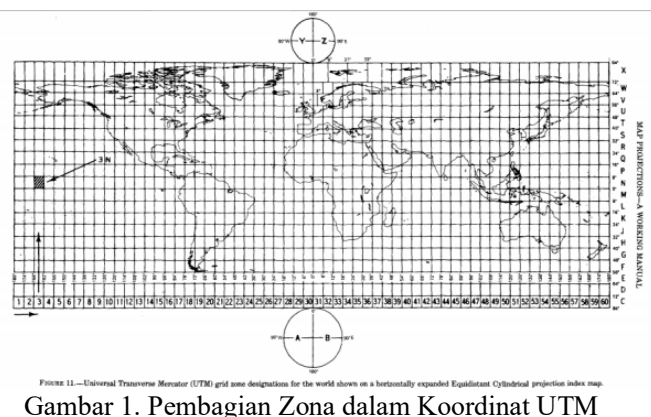




\section{METODE GRID}

Metode Grid dalam penelitian ini digunakan untuk menentukan titik lokasi lumbung padi dengan memperhitungkan total biaya transportasi yang akan dikeluarkan dalam pendistribusian padi berdasarkan koordinat lokasi yang akan menerima pendistribusian padi. Metode grid dipilih dalam menyelesaikan masalah dalam penelitian ini karena metode ini mampu menentukan dua lokasi lumbung padi sekaligus. Sedangkan metode yang lain seperti halnya Gravity Location Models (GLM) yang cukup sulit untuk menentukan dua lokasi lumbung padi. Keakuratan dari metode ini cukup baik, karena memiliki selisih yang tidak terlalu besar dengan metode yang lain, terutama dalam penentuan satu lokasi lumbung.

Metode ini dapat diuraikan sebagai berikut. Diberikan sebanyak $n$ koordinat lokasi yang akan menerima pasokan padi dengan koordinat $\left(x_{i}, y_{i}\right)$, dimana $i=1,2, \ldots, \mathrm{n}$ dan $V_{i}$ (dalam ton) yang merupakan volume padi yang akan dipindahkan berdasarkan tiap lokasi yang akan menerima pasokan padi. Selain itu, koordinat $(x, y)$ merupakan lokasi lumbung padi.

Jarak Euclid atau Euclidean distance merupakan perhitungan jarak dari dua buah titik dalam Euclidean Space (ruang Euclid). Jarak Euclid diperkenalkan oleh seorang matematikawan dari Yunani sekitar tahun 300 B.C.E. Perhitungan jarak Euclid bekaitan dengan Teorema Phytagoras. Dan dalam penerapannya akan digunakan pada dua dimensi dan koordinat yang digunakan dalam perhitungan adalah koordinat UTM. Persamaan (1) merupakan persamaan yang digunakan untuk menghitung jarak Euclid dua lokasi pada zona yang sama. Menurut Ama, dkk (2015) persamaan untuk menghitung jarak Euclid dapat ditulis seperti persamaan (1) sebagai berikut:

$$
F_{n}=\sqrt{\left(x-x_{n}\right)^{2}+\left(y-y_{n}\right)^{2}}
$$

Sedangkan jarak Euclid untuk beda zona dapat dihitung dengan memperhatikan Gambar 2 dan langkah-langkah di bawah ini.

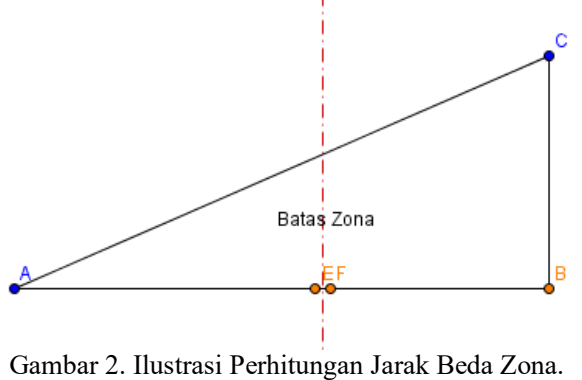

Adapun langkah-langkah yang digunakan dalam perhitungan yaitu:

L.1 Menentukan titik koordinat $B, E$, dan $F$. Dimana nilai titik $E$ dan $F$ tidak sama dengan batas zona dan mendekati batas zona.
L.2 Menghitung jarak Euclid antara $A$ dan $E, F$ dan $B$, serta $B$ dan $C$. Jarak euclid dapat digunakan karena kedua titik tersebut berada pada satu zona yang sama.

L.3 Hasil perhitungan jarak euclid dari $A$ dan $B$, serta $F$ dan $B$ dijumlahkan sehingga akan mewakili jarak dari $A$ dan $B$.

L.4 Dengan menggunakan rumus Phytagoras atau persamaan Phytagoras dihitunglah jarak $A$ dan $C$ dari jarak $A$ dan $B$, serta jarak $B$ dan $C$.

Rumus Phytagoras atau persamaan Phytagoras yang digunakan ditunjukkan pada persamaan (2) sebagai berikut.

$$
A C=\sqrt{(A B)^{2}+(B C)^{2}}
$$

Pada persamaan (3) dibawah ini merupakan persamaan yang digunakan dalam perhitungan minimum jarak Euclid antara dua lokasi lumbung padi. Persamaan ini bertujuan untuk menentukan lebih dari satu kandidat lumbung padi. Menurut Setiawan dan Sediyono (2015) persamaan (3) dapat ditulis sebagai berikut.

$$
F_{n}=\min \left\{\sqrt{\left(x_{n}-x_{A}\right)^{2}+\left(y_{n}-y_{A}\right)^{2}}, \sqrt{\left(x_{n}-x_{B}\right)^{2}+\left(y_{n}-y_{B}\right)^{2}}\right\}
$$

Hal yang diperhitungan selanjutnya adalah perhitungan dalam meminimumkan total biaya (total cost/TC) yang akan dikeluarkan. Dalam perhitungannya, diperlukan nilai hasil perhitungan jarak Euclid $\left(F_{i}\right)$ dalam satuan kilometer $(\mathrm{km})$ dan $V_{i}$. Persamaan (4) adalah persamaan yang digunakan untuk menentukan TC mengikuti Partiban dan Sundararaj (2013). Persamaan (4) dapat dilihat sebagai berikut.

$T C=\sum_{n=1}^{k} d_{n} V_{n} F_{n}$

Berikut diberikan langkah perhitungan dalam menentukan dua lokasi lumbung padi dengan menggunakan data kecil yaitu data empat kabupaten yang ada di Provinsi Kalimantan Tengah.

Tabel 1 di bawah ini menunjukan data lokasi keempat kabupaten/kota yang diwakili lokasi kantor bupati/wali kota berdasarkan koordinat Geografis. Keempat data dibawah ini merupakan data acak yang diambil dari 14 data kabupaten/kota di Provinsi Kalimantan Tengah tanpa memperhitungkan zona lokasi-lokasi kabupaten tersebut.

Tabel 1. Lokasi Kabupaten Berdasarkan Koordinat Geografis

\begin{tabular}{lcc}
\hline \multirow{2}{*}{ Kabupaten } & \multicolumn{2}{c}{ Koordinat Geografis } \\
& Longitude & Latitude \\
\hline Gunung Mas & 113.7407325 & -1.0927413 \\
Lamandau & 113.1866916 & -1.3495359 \\
Barito Selatan & 114.5920465 & -1.9983047 \\
Barito Timur & 115.0282835 & -1.9939326 \\
\hline
\end{tabular}


Salah satu lokasi kabupaten yang akan dijadikan contoh perhitungan konversi koordinat Geografis ke koordinat UTM adalah Kabupaten Gunung Mas. Titik lokasi kabupaten ini dapat dilihat pada Gambar 3 di bawah ini.

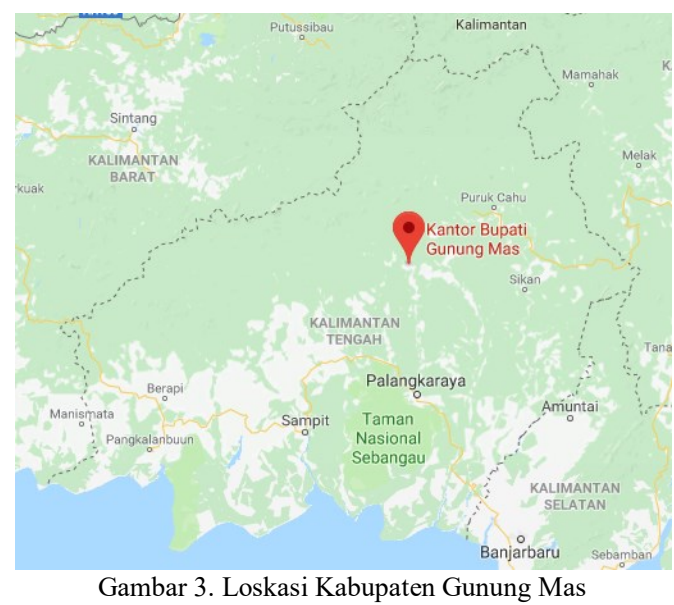

Adapun titik koordinat longitude dan latitude kantor bupati Gunung Mas yaitu $(\lambda, \phi)=(113.7407325,-1.0927413) \quad$ untuk diproyeksikan ke dalam koordinat UTM dengan menggunakan rumus dari Hager, dkk (1989) sebagai berikut.

$$
\begin{array}{ll}
f=0.00335281066478 & T_{3}=-25623.0038031 \\
e^{2}=0.0066943799902 & T_{4}=-10598.4278554 \\
e^{\prime 2}=0.00673949674233 & T_{5}=-4167.832853 \\
n=0.0016792203864 & T_{6}=6374434.01682 \\
v=6378144.76447 & T_{7}=1068787.7595 \\
S=-120829.225007 & T_{8}=270091.010189 \\
\Delta \lambda=0.0478348060414 & T_{9}=76846.595618 \\
T_{1}=-120780.893317 &
\end{array}
$$

Berdasarkan nilai-nilai diatas dapat diperoleh nilai proyeksi dalam koordinat UTM yang berupa Easting (E) sebesar 805036.865714 dan Northing (N) sebesar 9879079.891317 dan terletak di zona 49.

Tabel 2 merupakan hasil konversi koordinat Geografis ke koordinat UTM berdasarkan data pada Tabel 1 dengan menggunakan cara yang sama dengan konversi koordinat Geografis ke koordinat UTM Kabupaten Gunung Mas.

Tabel 2. Data Koordinat Keempat Lokasi Kabupaten

\begin{tabular}{lrr}
\multicolumn{1}{c}{ Kabupaten } & Koordinat E & Koordinat N \\
\hline Gunung Mas & 805036.865714 & 9879079.891317 \\
Lamandau & 743316.392692 & 9850726.06503 \\
Barito Selatan & 232137.719849 & 9778930.03040 \\
Barito Timur & 280685.797732 & 9779478.30692 \\
\hline
\end{tabular}

\begin{tabular}{llll}
\multicolumn{4}{c}{ Tabel 3. Data Jumlah Penduduk, Produksi Padi, dan Volume } \\
Bahan Pangan \\
\hline Kabupaten & Penduduk & Produksi & Volume \\
\hline Gunung Mas & 109947 & 16646 & 1396.351 \\
Lamandau & 73975 & 49772 & 39511.67 \\
Barito Selatan & 131987 & 37058 & 18751.40 \\
Barito Timur & 113696 & 62286 & 46516.37 \\
\hline
\end{tabular}

Berdasarkan Tabel 1. dapat digunakan untuk menentukan pasangan lokasi kandidat lumbung padi sebanyak 72 buah dengan nilai kandidat ke-72 buah tersebut dapat dilihat pada Tabel 4. Kandidat lumbung padi ini diambil dari suatu nilai yang mendekati keempat lokasi kabupaten.

Setelah mengetahui pasangan kandidat lokasi lumbung padi yang dapat dilihat pada Tabel 4, dapat dilakukan perhitungan selanjutnya yaitu dengan mencari minimum jarak Euclid antara setiap pasangan kandidat lumbung padi dengan keempat lokasi kabupaten.

Dalam menentukan minimum jarak Euclid dapat menggunakan persamaan (3) secara langsung maupun dengan menentukan jarak masing-masing antara kandidat I terhadap lokasi kabupaten dan jarak Euclid kandidat II terhadap lokasi kabupaten, dan selanjutnya dipilih nilai minimum antara jarak kedua kandidat tersebut dalam satu lokasi.

Setelah diperoleh nilai minimum jarak Eucli, maka dapat ditentukan nilai TC atau total biaya yang akan dikeluarkan berdasarkan persamaan (4). Tabel 5 berikut ini berisi nilai TC dari ke-72 pasangan kandidat lokasi lumbung padi.

Pada hasil Tabel 5 mengenai nilai TC, dapat diketahui bahwa nilai minimum TC terdapat pada pasangan ke-44 dan ke-60, Kedua pasangan tersebut memiliki nilai TC yang sama yaitu Rp. $41,76,341.81035$ pada pasangan ke-44 lokasi pertama $(-1.09,113.33)$ dan lokasi kedua $1.695,115.1)$, sedangkan pada pasangan ke-60 kedua lokasi pada pasangan ke-44 hanya dibalik yaitu lokasi pertama (-1.695,115.1) dan lokasi kedua ($1.09,113.33)$.

Dari hasil di atas dapat dikatakan bahwa kedua lokasi lumbung padi terdapat pada koordinat (1.09,113.33) yang terletak di dekat Desa Tehang, Kecamatan Manuhing Raya, Kabupaten Gunung Mas, Kalimantan Tengah dan koordinat

1.695,115.1) tepatnya di Desa Lebo, Kecamatan Pematang Karau, Kabupaten Barito Timur, Kalimantan Tengah.

Dari hasil perhitungan dua lokasi lumbung padi diatas dapat dibuat gambar plot yang berisi keempat lokasi kabupaten dan kedua lokasi lumbung padi seperti pada Gambar 4. Dalam Gambar 4 titik hitam mewakili lokasi kabupaten sedangkan titik merah mewakili lokasi lumbung padi. 
Tabel 4. Kandidat Pasangan Lumbung (PL)

\begin{tabular}{|c|c|c|c|c|}
\hline \multirow{2}{*}{ PL } & \multicolumn{2}{|c|}{ Kandidat I } & \multicolumn{2}{|c|}{ Kandidat II } \\
\hline & Long & Lat & Long & Lat \\
\hline 1 & 111.56 & -2.3 & 111.56 & -2.3 \\
\hline 2 & 111.56 & -2.3 & 111.56 & -1.695 \\
\hline 3 & 111.56 & -2.3 & 111.56 & -1.09 \\
\hline 4 & 111.56 & -2.3 & 113.33 & -2.3 \\
\hline 5 & 111.56 & -2.3 & 113.33 & -1.695 \\
\hline 6 & 111.56 & -2.3 & 113.33 & -1.09 \\
\hline 7 & 111.56 & -2.3 & 115.1 & -2.3 \\
\hline 8 & 111.56 & -2.3 & 115.1 & -1.695 \\
\hline 9 & 111.56 & -1.695 & 115.1 & -1.09 \\
\hline 10 & 111.56 & -1.695 & 111.56 & -2.3 \\
\hline 11 & 111.56 & -1.695 & 111.56 & -1.695 \\
\hline 12 & 111.56 & -1.695 & 111.56 & -1.09 \\
\hline 13 & 111.56 & -1.695 & 113.33 & -2.3 \\
\hline 14 & 111.56 & -1.695 & 113.33 & -1.695 \\
\hline 15 & 111.56 & -1.695 & 113.33 & -1.09 \\
\hline 16 & 111.56 & -1.695 & 115.1 & -2.3 \\
\hline 17 & 111.56 & -1.09 & 115.1 & -1.695 \\
\hline 18 & 111.56 & -1.09 & 115.1 & -1.09 \\
\hline 19 & 111.56 & -1.09 & 111.56 & -2.3 \\
\hline 20 & 111.56 & -1.09 & 111.56 & -1.695 \\
\hline 21 & 111.56 & -1.09 & 111.56 & -1.09 \\
\hline 22 & 111.56 & -1.09 & 113.33 & -2.3 \\
\hline 23 & 111.56 & -1.09 & 113.33 & -1.695 \\
\hline 24 & 111.56 & -1.09 & 113.33 & -1.09 \\
\hline 25 & 113.33 & -2.3 & 115.1 & -2.3 \\
\hline 26 & 113.33 & -2.3 & 115.1 & -1.695 \\
\hline 27 & 113.33 & -2.3 & 115.1 & -1.09 \\
\hline 28 & 113.33 & -2.3 & 111.56 & -2.3 \\
\hline 29 & 113.33 & -2.3 & 111.56 & -1.695 \\
\hline 30 & 113.33 & -2.3 & 111.56 & -1.09 \\
\hline 31 & 113.33 & -2.3 & 113.33 & -2.3 \\
\hline 32 & 113.33 & -2.3 & 113.33 & -1.695 \\
\hline 33 & 113.33 & -1.695 & 113.33 & -1.09 \\
\hline 34 & 113.33 & -1.695 & 115.1 & -2.3 \\
\hline 35 & 113.33 & -1.695 & 115.1 & -1.695 \\
\hline 36 & 113.33 & -1.695 & 115.1 & -1.09 \\
\hline 37 & 113.33 & -1.695 & 111.56 & -2.3 \\
\hline 38 & 113.33 & -1.695 & 111.56 & -1.695 \\
\hline 39 & 113.33 & -1.695 & 111.56 & -1.09 \\
\hline 40 & 113.33 & -1.695 & 113.33 & -2.3 \\
\hline 41 & 113.33 & -1.09 & 113.33 & -1.695 \\
\hline 42 & 113.33 & -1.09 & 113.33 & -1.09 \\
\hline 43 & 113.33 & -1.09 & 115.1 & -2.3 \\
\hline 44 & 113.33 & -1.09 & 115.1 & -1.695 \\
\hline 45 & 113.33 & -1.09 & 115.1 & -1.09 \\
\hline 46 & 113.33 & -1.09 & 111.56 & -2.3 \\
\hline 47 & 113.33 & -1.09 & 111.56 & -1.695 \\
\hline 48 & 113.33 & -1.09 & 111.56 & -1.09 \\
\hline 49 & 115.1 & -2.3 & 113.33 & -2.3 \\
\hline 50 & 115.1 & -2.3 & 113.33 & -1.695 \\
\hline 51 & 115.1 & -2.3 & 113.33 & -1.09 \\
\hline 52 & 115.1 & -2.3 & 115.1 & -2.3 \\
\hline 53 & 115.1 & -2.3 & 115.1 & -1.695 \\
\hline 54 & 115.1 & -2.3 & 115.1 & -1.09 \\
\hline 55 & 115.1 & -2.3 & 111.56 & -2.3 \\
\hline 56 & 115.1 & -2.3 & 111.56 & -1.695 \\
\hline 57 & 115.1 & -1.695 & 111.56 & -1.09 \\
\hline 58 & 115.1 & -1.695 & 113.33 & -2.3 \\
\hline 59 & 115.1 & -1.695 & 113.33 & -1.695 \\
\hline 60 & 115.1 & -1.695 & 113.33 & -1.09 \\
\hline 61 & 115.1 & -1.695 & 115.1 & -2.3 \\
\hline 62 & 115.1 & -1.695 & 115.1 & -1.695 \\
\hline 63 & 115.1 & -1.695 & 115.1 & -1.09 \\
\hline 64 & 115.1 & -1.695 & 111.56 & -2.3 \\
\hline 65 & 115.1 & -1.09 & 111.56 & -1.695 \\
\hline 66 & 115.1 & -1.09 & 111.56 & -1.09 \\
\hline 67 & 115.1 & -1.09 & 113.33 & -2.3 \\
\hline 68 & 115.1 & -1.09 & 113.33 & -1.695 \\
\hline 69 & 115.1 & -1.09 & 113.33 & -1.09 \\
\hline 70 & 115.1 & -1.09 & 115.1 & -2.3 \\
\hline 71 & 115.1 & -1.09 & 115.1 & -1.695 \\
\hline 72 & 115.1 & -1.09 & 115.1 & -1.09 \\
\hline
\end{tabular}

Tabel 5. Total Cost Tiap Kandidat Pasangan Lumbung Padi.

\begin{tabular}{|c|c|}
\hline Pasangan 1 & Pasangan 2 \\
\hline 71553001.42887 & 70556910.47159 \\
\hline Pasangan 3 & Pasangan 4 \\
\hline 70478416.88514 & 67296323.61456 \\
\hline Pasangan 5 & Pasangan 6 \\
\hline 64646525.15023 & 64259096.76891 \\
\hline Pasangan 7 & Pasangan 8 \\
\hline 11399174.09608 & 11314434.51551 \\
\hline Pasangan 9 & Pasangan 10 \\
\hline 14347476.11193 & 70556910.47159 \\
\hline Pasangan 11 & Pasangan 12 \\
\hline 70557022.13105 & 70477236.75712 \\
\hline Pasangan 13 & Pasangan 14 \\
\hline 67295143.48654 & 64645345.02220 \\
\hline Pasangan 15 & Pasangan 16 \\
\hline 64257916.64089 & 10439688.47661 \\
\hline Pasangan 17 & Pasangan 18 \\
\hline 10287651.09913 & 14280178.31502 \\
\hline Pasangan 19 & Pasangan 20 \\
\hline 70478416.88514 & 70477236.75712 \\
\hline Pasangan 21 & Pasangan 22 \\
\hline 70778383.67245 & 67596290.40187 \\
\hline Pasangan 23 & Pasangan 24 \\
\hline 64946491.93753 & 64559063.55622 \\
\hline Pasangan 25 & Pasangan 26 \\
\hline 7247394.92540 & 7213568.65600 \\
\hline Pasangan 27 & Pasangan 28 \\
\hline 11225651.46659 & 67296323.61456 \\
\hline Pasangan 29 & Pasangan 30 \\
\hline 67295143.48654 & 67596290.40187 \\
\hline Pasangan 31 & Pasangan 32 \\
\hline 80141631.20663 & 77490761.02981 \\
\hline Pasangan 33 & Pasangan 34 \\
\hline 77103426.07009 & 4597596.46106 \\
\hline Pasangan 35 & Pasangan 36 \\
\hline 4563770.19167 & 8575853.00225 \\
\hline Pasangan 37 & Pasangan 38 \\
\hline 64646525.15023 & 64645345.02220 \\
\hline Pasangan 39 & Pasangan 40 \\
\hline 64946491.93753 & 77490761.02981 \\
\hline Pasangan 41 & Pasangan 42 \\
\hline 77103426.07009 & 77354041.38066 \\
\hline Pasangan 43 & Pasangan 44 \\
\hline 4210168.07974 & 4176341.81035 \\
\hline Pasangan 45 & Pasangan 46 \\
\hline 8188424.62093 & 64259096.76891 \\
\hline Pasangan 47 & Pasangan 48 \\
\hline 64257916.64089 & 64559063.55622 \\
\hline Pasangan 49 & Pasangan 50 \\
\hline 7247394.92540 & 4597596.46106 \\
\hline Pasangan 51 & Pasangan 52 \\
\hline 4210168.07974 & 12517265.31210 \\
\hline Pasangan 53 & Pasangan 54 \\
\hline 11596146.40621 & 11554052.04160 \\
\hline Pasangan 55 & Pasangan 56 \\
\hline 11399174.09608 & 10439688.47661 \\
\hline Pasangan 57 & Pasangan 58 \\
\hline 10287651.09913 & 7213568.65600 \\
\hline Pasangan 59 & Pasangan 60 \\
\hline 4563770.19167 & 4176341.81035 \\
\hline Pasangan 61 & Pasangan 62 \\
\hline 11596146.40621 & 11598012.65980 \\
\hline Pasangan 63 & Pasangan 64 \\
\hline 11520225.77221 & 11314434.51551 \\
\hline Pasangan 65 & Pasangan 66 \\
\hline 14347476.11193 & 14280178.31502 \\
\hline Pasangan 67 & Pasangan 68 \\
\hline 11225651.46659 & 8575853.00225 \\
\hline Pasangan 69 & Pasangan 70 \\
\hline 8188424.62093 & 11554052.04160 \\
\hline Pasangan 71 & Pasangan 72 \\
\hline 11520225.77221 & 15532308.58279 \\
\hline
\end{tabular}




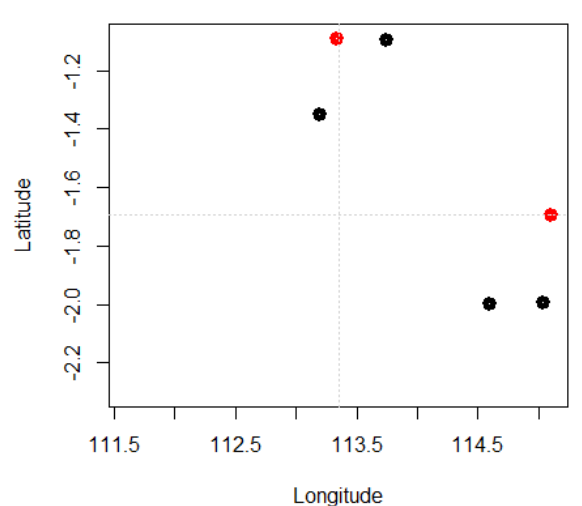

Gambar 4. Plot Lokasi Kabupaten dan Lumbung Padi

Pada Gambar 5 dan Gambar 6 merupakan gambar yang menunjukkan lokasi lumbung padi pertama dan kedua pada aplikasi Google Maps. Gambar 5 adalah lokasi lumbung padi di Desa Tehang, Kabupaten Gunung Mas, sedangkan Gambar 6 adalah lokasi lumbung padi di Desa Lebo, Kabupaten Barito Timur.

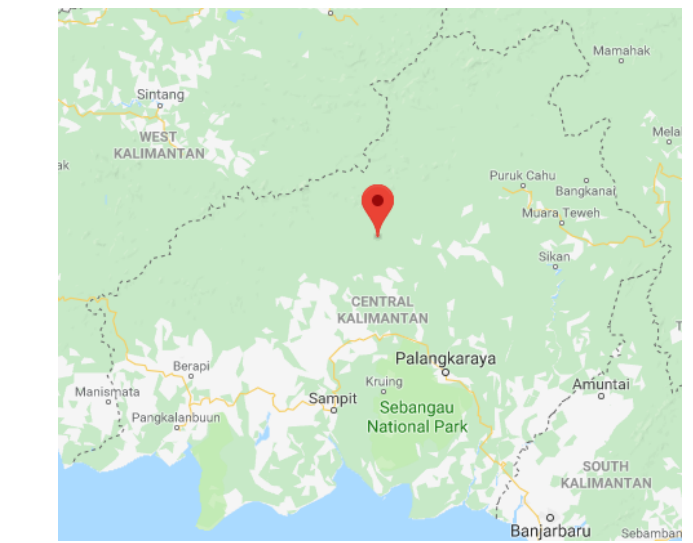

Gambar 5. Lokasi Pertama Lumbung Padi pada Aplikasi Google Maps

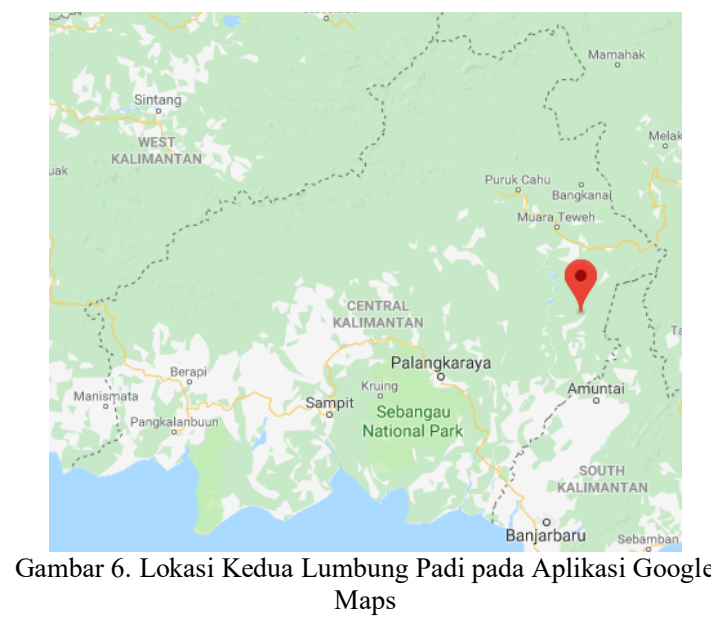

\section{HASIL PEMBAHASAN}

Dalam hasil pembahasan berikut ini akan diberikan hasil perhitungan dengan menggunakan 14 kabupaten di Provinsi Kalimantan Tengah. Koordinat lokasi kabupaten ini dicari dengan bantuan aplikasi
Google Maps. Pada Tabel 6 diberikan data mengenai koordinat Geografis ke-14 lokasi kabupaten yang diwakili oleh kantor bupati.

\begin{tabular}{lcc}
\multicolumn{2}{c}{ Tabel 6. Koordinat Geografis Lokasi Kabupaten di Kalimantan } \\
Tengah
\end{tabular}

Sedangkan pada Tabel 7 diberikan data mengenai koordinat ke-14 lokasi kabupaten di Provinsi Kalimantan Tengah yang telah dikonversikan kedalam koordinat UTM.

Tabel 7. Koordinat UTM Lokasi Kabupaten di Kalimantan

\begin{tabular}{lcc}
\multicolumn{1}{c}{ Tengah } & \\
\hline \multicolumn{1}{c}{ Kabupaten } & Koordinat N & Koordinat E \\
\hline Gunung Mas & 9879079.8913 & 805036.86571 \\
Kapuas & 9671967.9698 & 212516.86936 \\
Katingan & 9813483.7696 & 721102.92816 \\
Kotawaringin & 9713353.9336 & 573098.25682 \\
Barat & & \\
Kotawaringin & 9748434.4740 & 666967.42734 \\
Timur & & \\
Lamandau & 9850726.0650 & 743316.39269 \\
Sukamara & 9706191.7689 & 519628.63052 \\
Seruyan & 9622495.3243 & 671266.60639 \\
Palangka Raya & 9754953.0427 & 819226.78078 \\
Barito Selatan & 9778930.0304 & 232137.71985 \\
Barito Timur & 9779478.3069 & 280685.79773 \\
Barito Utara & 9779357.7358 & 171446.54048 \\
Murung Raya & 9932525.6201 & 182971.45705 \\
Pulang Pisau & 9698710.0326 & 187207.59537 \\
\hline
\end{tabular}

Tabel 8 diberikan data mengenai jumlah penduduk dan data jumlah produksi padi berdasarkan tiap kabupaten. 
Tabel 8. Jumlah Penduduk dan Jumlah Produksi Padi

\begin{tabular}{lll}
\hline \multicolumn{1}{c}{ Kabupaten } & \multicolumn{1}{c}{ Jumlah } & \multicolumn{1}{c}{ Jumlah } \\
& Penduduk & Produksi Padi \\
\hline Gunung Mas & 109947 & 16646 \\
Kapuas & 348049 & 793100 \\
Katingan & 160305 & 124636 \\
Kotawaringin Barat & 278141 & 59296 \\
Kotawaringin Timur & 426176 & 97076 \\
Lamandau & 73975 & 49772 \\
Sukamara & 55321 & 19062 \\
Seruyan & 174859 & 33126 \\
Palangka Raya & 259865 & 82 \\
Barito Selatan & 131987 & 37058 \\
Barito Timur & 113696 & 62286 \\
Barito Utara & 127479 & 50960 \\
Murung Raya & 110390 & 41286 \\
Pulang Pisau & 124845 & 240918 \\
\hline & & \\
\hline
\end{tabular}

Berdasarkan data pada Tabel 6, Tabel 7, dan Tabel 8 akan ditentukan dua lokasi lumbung padi dengan sejumlah 14,520 pasangan kandidat lumbung padi. Dimana nilai kandidat $x$ memiliki selisih nilai 0.3 dari -3 sampai 0 , sedangkan nilai kandidat $y$ memiliki selisih nilai 0.6 dari nilai 110 sampai 116 . Bila koordinat tersebut dituangkan menjadi satu dalam suatu plot, akan membentuk grid, inilah langkah awal dalam metode grid ini. Berikut pada Tabel 9 akan diberikan sebagian kecil nilai pasangan kandidat lumbung padi berdasarkan koordinat Geografis.

Tabel 9. Pasangan Kandidat Lokasi Lumbung Padi

\begin{tabular}{ccccc}
\hline \multirow{2}{*}{ PL } & \multicolumn{2}{c}{ Kandidat I } & \multicolumn{2}{c}{ Kandidat II } \\
& Long & Lat & Long & Lat \\
\hline 1 & 110 & -3 & 110 & -3 \\
2 & 110 & -3 & 110 & -2.7 \\
3 & 110 & -3 & 110 & -2.4 \\
4 & 110 & -3 & 110 & -2.1 \\
5 & 110 & -3 & 110 & -1.8 \\
6 & 110 & -3 & 110 & -1.5 \\
7 & 110 & -3 & 110 & -1.2 \\
8 & 110 & -3 & 110 & -0.9 \\
9 & 110 & -3 & 110 & -0.6 \\
10 & 110 & -3 & 110 & -0.3 \\
11 & 110 & -3 & 110 & 0 \\
$\ldots$ & $\ldots$ & $\ldots$ & $\ldots$ & $\ldots$ \\
14510 & 116 & 0 & 116 & -3 \\
14511 & 116 & 0 & 116 & -2.7 \\
14512 & 116 & 0 & 116 & -2.4 \\
14513 & 116 & 0 & 116 & -2.1 \\
14514 & 116 & 0 & 116 & -1.8 \\
14515 & 116 & 0 & 116 & -1.5 \\
14516 & 116 & 0 & 116 & -1.2 \\
14517 & 116 & 0 & 116 & -0.9 \\
14518 & 116 & 0 & 116 & -0.6 \\
14519 & 116 & 0 & 116 & -0.3 \\
14520 & 116 & 0 & 116 & 0 \\
\hline
\end{tabular}

Berdasarkan langkah yang sama dalam proses penentuan dua lokasi lumbung padi pada data kecil, maka berdasarkan data pada Tabel 6, Tabel 7, Tabel 8, dan Tabel 9 dapat ditentukan nilai TC pada masing-masing pasangan kandidat lumbung padi. Nilai TC hasil perhitungan tersebut sebagian kecil terdapat pada Tabel 10 berikut ini.

Tabel 10. Nilai TC Setiap Pasangan Lokasi Lumbung Padi

\begin{tabular}{|c|c|}
\hline Pasangan 1 & Pasangan 2 \\
\hline 984779802.6945 & 982003149.9694 \\
\hline Pasangan 3 & Pasangan 4 \\
\hline 980283649.7975 & 979141915.0448 \\
\hline Pasangan 5 & Pasangan 6 \\
\hline 978554040.8599 & 978575401.2231 \\
\hline Pasangan 7 & Pasangan 8 \\
\hline 979109210.5631 & 980165504.1848 \\
\hline Pasangan 9 & Pasangan 10 \\
\hline 981405883.1289 & 982717574.0849 \\
\hline Pasangan 11 & Pasangan 12 \\
\hline 983237755.7914 & 973602172.4103 \\
\hline Pasangan 13 & Pasangan 14 \\
\hline 971121504.0997 & 969566404.2140 \\
\hline Pasangan 15 & Pasangan 16 \\
\hline 968955037.1041 & 969217724.0048 \\
\hline Pasangan 17 & Pasangan 18 \\
\hline 970056695.5920 & 971204700.9639 \\
\hline Pasangan 19 & Pasangan 20 \\
\hline 972504985.5999 & 974335550.5853 \\
\hline$\ldots$ & $\ldots$ \\
\hline Pasangan 14499 & Pasangan 14500 \\
\hline 199121549.7040 & 196709963.0212 \\
\hline Pasangan 14501 & Pasangan 14502 \\
\hline 203630451.5793 & 218401039.2887 \\
\hline Pasangan 14503 & Pasangan 14504 \\
\hline 239124448.7350 & 264825237.0755 \\
\hline Pasangan 14505 & Pasangan 14506 \\
\hline 293909597.7399 & 325468043.2287 \\
\hline Pasangan 14507 & Pasangan 14508 \\
\hline 358959661.5930 & 394007234.6759 \\
\hline Pasangan 14509 & Pasangan 14510 \\
\hline 430309956.8931 & 278677562.1328 \\
\hline Pasangan 14511 & Pasangan 14512 \\
\hline 277091460.0369 & 281457105.2934 \\
\hline Pasangan 14513 & Pasangan 14514 \\
\hline 291954453.9017 & 307862835.6912 \\
\hline Pasangan 14515 & Pasangan 14516 \\
\hline 328329492.9852 & 352460429.1339 \\
\hline Pasangan 14517 & Pasangan 14518 \\
\hline 379333219.7320 & 408658980.2421 \\
\hline Pasangan 14519 & Pasangan 14520 \\
\hline 439979908.4581 & 472935254.8618 \\
\hline
\end{tabular}

Berdasarkan nilai TC pada Tabel 10 dapat diperoleh minimum TC pada pasangan ke-7096 dan ke-9256 dengan nilai TC sebesar Rp. 55,287,393.0814. Kedua koordinat lokasi tersebut adalah $(113,-1.8)$ tepatnya di Desa Koeling, Kecamatan Pundu, Kabupaten Kotawaringin Timur, Kalimantan Tengah dan $(114.2,-3)$ tepatnya di Desa Pangkuh, Kecamatan Pangkoh Hilir, Kabupaten Pulang Pisau, Kalimantan Tengah.

Dari hasil perhitungan tersebut dapat dibuat plot grid yang berisi lokasi ke-14 kabupaten dan kedua lokasi lumbung padi seperti pada Gambar 7. Dimana titik hitam merupakan lokasi ke-14 
kabupaten sedangkan titik merah merupakan pasangan lokasi lumbung padi.

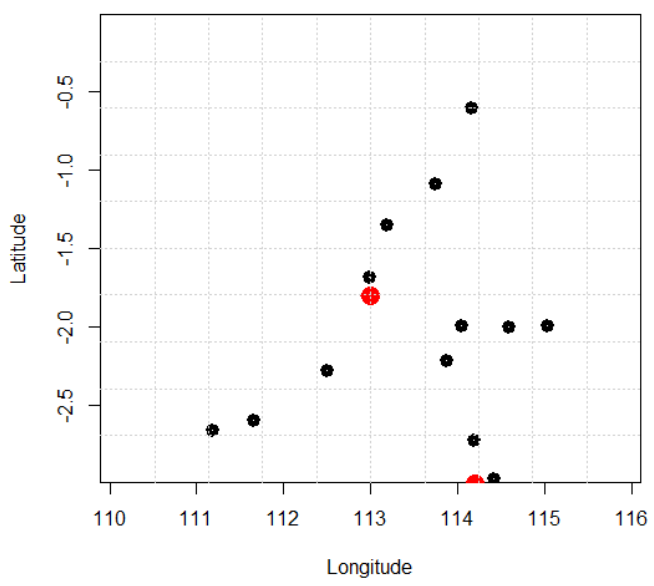

Gambar 7. Plot Lokasi Kabupaten dan Lokasi Lumbung Padi

Dari dua lokasi lumbung padi tersebut dapat dilihat letak lokasinya pada aplikasi Google Maps seperti pada Gambar 8 dan Gambar 9. Dimana Gambar 8 merupakan lokasi lumbung padi di Desa Koeling, Kabupaten Kotawaringin Timur sedangkan Gambar 9 merupakan lokasi lumbung padi di Desa Pangkuh, Kabupaten Pulang Pisau.

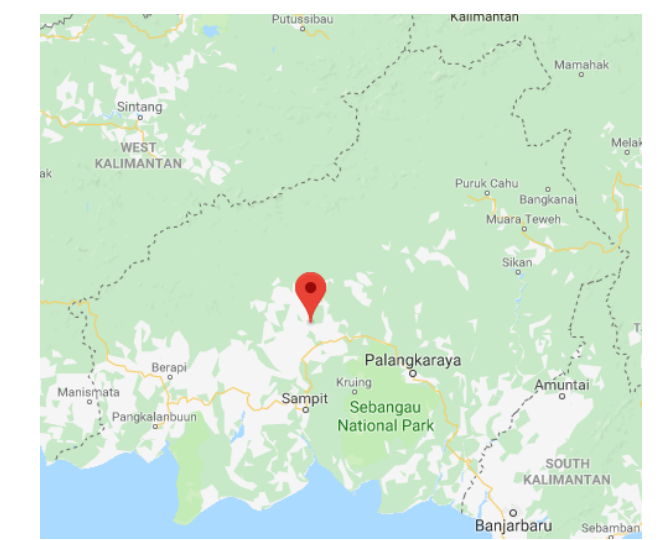

Gambar 8. Lokasi Lumbung Padi Pertama pada Aplikasi Google Maps

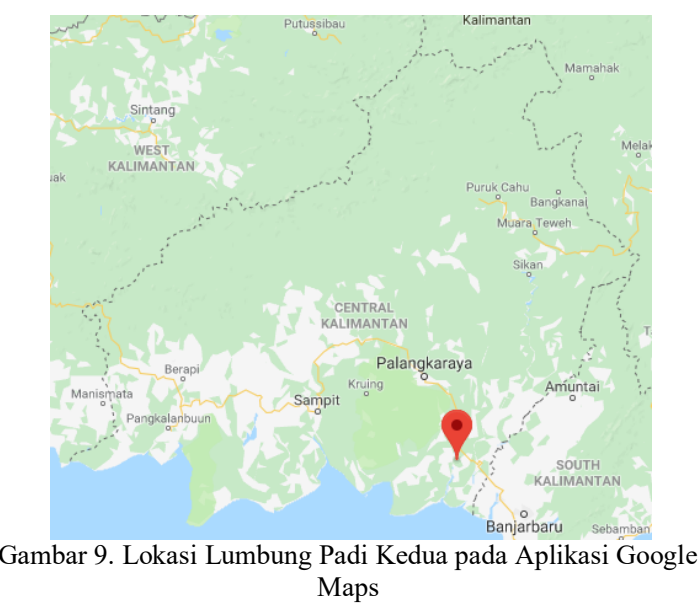

5. KESIMPULAN
Berdasarkan hasil perhitungan dalam penelitian ini dapat diketahui kedua lokasi lumbung padi dengan memperhitungkan total biaya yang akan dikeluarkan untuk pendistribusian bahan makanan padi. Berdasarkan koordinat Geografis terdapat pada $(-1.8,113)$ yang terletak di Desa Koeling, Kecamatan Pundu, Kabupaten Kotawaringin Timur, Kalimantan Tengah dan $(-3,114.2)$ yang terletak di Desa Pangkuh, Kecamatan Pulang Pisau, Kalimantan Tengah, dengan TC atau total biaya yang akan dikeluarkan untuk pendistribusian bahan pangan padi sebesar Rp. $55,287,393.08$.

Untuk penelitian selanjutnya, terdapat beberapa saran yaitu dengan mengganti dan menambah obyek lokasi, dalam perhitungan jarak dapat digunakan jarak Vincenty, dan jumlah lumbung yang akan ditentukan dapat diperbanyak.

\section{DAFTAR PUSTAKA}

AMA, A.U.T., SEDIYONO, E., DAN SETIAWAN, A., 2015. Rekayasa Algoritma Gravity Location Models untuk Penentuan Lokasi Lumbung Pangan Masyarakat Kabupaten Minahasa Tenggara.Jurnal Teknik Informatika dan Sitem Informasi, Vol. 1, No 3, Des 2015.

Badan Pusat Statistik Provinsi Kalimantan Tengah, 2013. Statistik Tanaman Pangan Kalimantan Tengah 2013. Kalimantan Tengah: Badan Pusat Statistik.

Badan Pusat Statistik Provinsi Kalimantan Tengah, 2015. Statistik Kependudukan Kalimantan Tengah 2015. Kalimantan Tengah: Badan Pusat Statistik.

HAGER, J. W., BEHENSKY, JAMES F., DREW, B. W. 1989. The Universal Grids: Universal Transverse Mercator (UTM) and Universal Polar Stereographic (UPS). Public Release: Distribution Unlimited.

HASNA, N. R., SETIAWAN, A., dan PARHUSIP, H. A. 2017. Penentuan Lokasi Lumbung Pangan Berdasarkan Gravity Location Models Dengan Koordinat UTM di Provinsi Maluku Utara. Jurnal Sains dan Edukasi Sains.

PARTHIBAN, P. dan SUNDARARAJ, G., 2013. Optimal Location of Base Station in a Wireless Sensor Network Using Gravity Location Model. Int. J. Eng. Comput. Sci. Vol: No. 11 pp. 3147-3151.

PRIHANDITO, A., 1998. Proyeksi Peta. Yogjakarta: Kanisius.

ROSITA, M., PUNJAWAN, I. N., dan ARVITRIDA, N., 2010. Simulasi Sistem Logistik Perkotaan untuk Memenuhi Pasokan Barang ke Rentail Modern di Surabaya dengan Penambahan Pusat Distribusi. Tesis ITS.

SARASWATI, T. G, 2015. Model Gravitasi Sebagai Alat Evaluasi dan Penentuan Lokasi Gudang 
pada Bisnis Rentail. Jurnal Bisnis dan Sosial. Vol. 1, No. 2.

SETIAWAN, A. DAN SEDIYONO, E. 2015. Application of Grid Method to Determine Location of Rice Warehouse in Minahasa Tenggara. Jurnal IComPAC.

UTAMA, R., 2007. Makanan Pokok Orang Indonesia. Scholar Articles [online] Tersedia di:

$<<$ http://www.scholar.google.co.id/scholar?oi $=$ bibs\&hl $=$ en \&cluster $=149130728762107028$

$73 \# \mathrm{~d}=$ gs_qabs\&u=\%23p\%3DGVNKoMTg9c $4 \mathrm{~J}>>$ [Diakses 26 September 2018]. 
Halaman ini sengaja dikosongkan 